\title{
DIFFERENCES IN KNEE SENSORIMOTOR CONTROL BY PHYSICAL ACTIVITY LEVEL AND SEX
}

\section{DIFERENÇAS NO CONTROLE SENSORIMOTOR DO JOELHO POR NÍVEL ATIVIDADE FÍSICA E SEXO}

\author{
Cristóbal San Martín-Mohr ${ }^{1,2}$, Andrés Valladares ${ }^{2,3}$, Iver Cristi ${ }^{4}$, Francisco José Berral ${ }^{5}$, Claudio Oyarzo ${ }^{2,6}$, Fernando Lira ${ }^{4}$ \\ 1. Carrera de Kinesiología, Departamento Ciencias de la salud, Facultad de Medicina, Pontificia Universidad Católica de Chile, Santiago, Chile. \\ 2. Clínica MEDS, Santiago, Chile. \\ 3. Universidad Finis Terrae, Santiago, Chile. \\ 4. Escuela de Kinesiología, Facultad de Ciencias, Universidad Mayor, Chile \\ 5. Universidad Pablo de Olavide ES-41013 Sevilla, Spain. \\ 6. Universidad de los Andes, Santiago, Chile.
}

\section{ABSTRACT}

Objective: The aim of this study was to compare the differences in knee sensorimotor control between healthy men and women by measuring the joint position sense (JPS), sensation of muscle tension (steadiness), and onset of muscle activation (OMA). Methods: Twenty-four healthy women and 27 healthy men were tested. Knee sensorimotor control was assessed using the JPS test with electrogoniometers in 3 different ranges of motion, sensation of muscle tension using the isometric steadiness technique, and OMA against a mechanical perturbation. Each assessment was compared by sex, physical activity level, and right or left lower limb. Results: The men obtained better values in the JPS test between $90^{\circ}$ and $60^{\circ}$ and between $30^{\circ}$ and $0^{\circ}$ than the women. The subjects with higher levels of physical activity also showed better values, between $90^{\circ}$ and $60^{\circ}$ and between $30^{\circ}$ and $0^{\circ}$. The best results for steadiness were found in the women and the subjects with higher levels of physical activity. In the OMA test, no significant differences were found in the studied variables. Conclusion: The results suggest that higher levels of physical activity may determine better sensorimotor control. Men have better articular sensation, and women have better muscle strength control. Level of evidence III, Cross sectional study.

Keywords: Knee. Physical Activity. Proprioception.

\section{RESUMO}

Objetivo: O objetivo desse estudo foi comparar as diferenças no controle sensório-motor de joelho entre mulheres e homens saudáveis medindo o sensação da posição articular (SPA), Coeficiente de variações da força (Steadiness) e inicio ou ativação muscular (IAM) Métodos: Foi avaliado 24 mulheres saudáveis e 27 homens saudáveis, realizando avaliações de SPA, o Sensação de tensão muscular (Steadiness) e o IAM, comparadas segundo sexo, nível de atividade física e extremidades inferiores direita ou esquerda. Resultados: SPA: Os homens obtiveram melhores valores nessa prova entre 90-60 ( $p=0,0127)$ e em $30-0^{\circ}(p=0,0017)$ ao comparado com as mulheres. as pessoas com maior nível de atividade física também se encontram melhores resultados entre 90-60 $(p=0,0328)$ e 30- $0^{\circ}(p=0,0173)$. STEADINESS: Os melhores resultados foram para as mulheres em ambas extremidades (direita $p=0,0002$ e esquerda $p=0,0009$ ) e pessoas com maior nível de atividade física (direita $p=0,0065$ e esquerda $p=0,0173)$. Para IAM não foi encontrado diferenças significativas nas variáveis estudadas. Conclusão: Os resultados sugerem que tanto maior nível de atividade física puderam determinar maior resultado no controle sensório-motor. Os homens tiveram maior sensação articular e as mulheres maior controle steadiness. Nível de evidência III, Estudo transversal.

Descritores: Joelho. Atividade física. Propriocepção.

Citation: Martín-Mohr CS, Valladares A, Cristi I, Berral FJ, Oyarzo C, Lira F. Differences in knee sensorimotor control by physical activity level and sex. Acta Ortop Bras. [online]. 2019;27(1):20-6. Available from URL: http://www.scielo.br/aob.

\section{INTRODUCTION}

The sensorimotor system (SSM) is responsible for transporting and integrating the sensory and motor information, central integration and processing of all components involved in maintaining articular homeostasis during body movements. ${ }^{1}$ This means that the SSM provides functional joint stability throughout human movements and an inadequate functioning of this system can predispose to articular injuries. ${ }^{2}$ Recent studies have shown that there are difference when evaluating the SSM between sex. ${ }^{3}$ Moreover, SSM differences have been found between at different levels of activity. ${ }^{4}$ Therefore, studies assessing the difference between gender and activity level are needed.

The main purpose of this study was to compare the differences in knee sensorimotor control combining measures of joint position

All authors declare no potential conflict of interest related to this article.

Study was conducted at the Clínica MEDS, Santiago Chile.

Correspondence: Cristóbal San Martín-Mohr Isabel La Católica 3740, Las Condes. Santiago. Chile. cristobalsanmartin@hotmail.com 
sense (JPS), steadiness and onset of muscle activation, relating them to level of physical activity, gender and differences between the two extremities.

\section{MATERIALS AND METHOD}

Subjects

The sample is composed of 51 voluntary healthy subjects; 27 men $(24,27 \pm 3,28$ years; $1,76 \pm 0,06 \mathrm{~m} ; 75,91 \pm 8,54 \mathrm{Kg})$ and 24 women $(24,67 \pm 3,53$ years; $1,64 \pm 0,06 \mathrm{~m} ; 58,71 \pm 8,73 \mathrm{Kg})$, with a level of physical activity with a score of 2 to 8 on the Tegner's scale. ${ }^{5}$ Each one of the participants signed an informed consent previous to the assessments that were performed. This study was approved by the bioethics committee of the Pontificia Universidad Católica de Chile (Protocol number 14-146).

\section{Outcomes Measurement}

\section{JPS Test}

The aim of this test was to evaluate JPS, the ability of subjects to actively replicate a previously determined joint position. A uniaxial electrogoniometer (Kinectecnic Ltda, Santiago, Chile) for the measurement of the knee articular angle in 3 ranges of motion was used: $90^{\circ}-60^{\circ}, 60^{\circ}-30^{\circ}$ y $30^{\circ}-0^{\circ}$ (Figure $1 \mathrm{~A}$ ). The subject was in sitting position with their knees initially in $90^{\circ}$ of flexion. In each repetition the difference between the angle reached by the subject and the target angle is calculated by averaging the difference of 10 repetitions for each angle and extremity. For signal processing, the Igor Pro 6.0 (WaveMetrics Inc, Lake Oswego, USA) program was used.

\section{Steadiness. Sensation of muscle tension}

The purpose of this assessment was to evaluate the ability of subjects to maintain a constant force at $15 \%$ of maximum voluntary isometric contraction, which reflects fine muscle control. ${ }^{6}$ First, the maximum voluntary isometric contraction (MVIC) was assessed. The patient was sitting with a knee flexion angle of approximately $90^{\circ}$ anchoring to the distal end of the leg a load cell where the subjects were asked to perform a maximum isometric voluntary contraction of the extensor muscles of the knee. This was measured using an S beam load cell (Interface, Arizona, USA). The signal was captured using a Trigno Wireless System (Delsys, Boston, USA) with a sampling frequency of $2000 \mathrm{~Hz}$.

Knee isometric steadiness was evaluated with the same setup as the MVIC assessment. Each subject was asked to exert knee extensor force to reach a specific target, a trapezoidal figure which represented the $15 \%$ of their MVIC (Figure 1B). Subjects were asked to reproduce this paradigm that lasted 20 seconds. To quantify fine muscular control, the coefficient of variation was calculated between the paradigm displayed on the screen and the exerted force of the the subject

\section{Onset of Muscle Activation}

The onset of muscle activation in the knee muscles was estimated utilizing surface electromyography, a method that was previously used in other studies. ${ }^{7}$ EMG bipolar sensors (Delsys, Boston, USA) were positioned on the vastus medialis, vastus lateralis, semitendinosus, and biceps femoris muscles of each subject according to SENIAM recommendations. ${ }^{8}$ The subjects were ask to stand over two destabilizing platforms (Figure 1C). A sudden fall of the platforms causes $20^{\circ}$ of inversion at the ankle in a weight-bearing condition. The drop of the platforms was captured with a triaxial accelerometer, which was synchronized with sEMG signals. Both signals were sampled at $2000 \mathrm{hz}$. Activation latency for each muscle was calculated as delta time between the onset of acceleration during perturbation and onset of muscle activation.
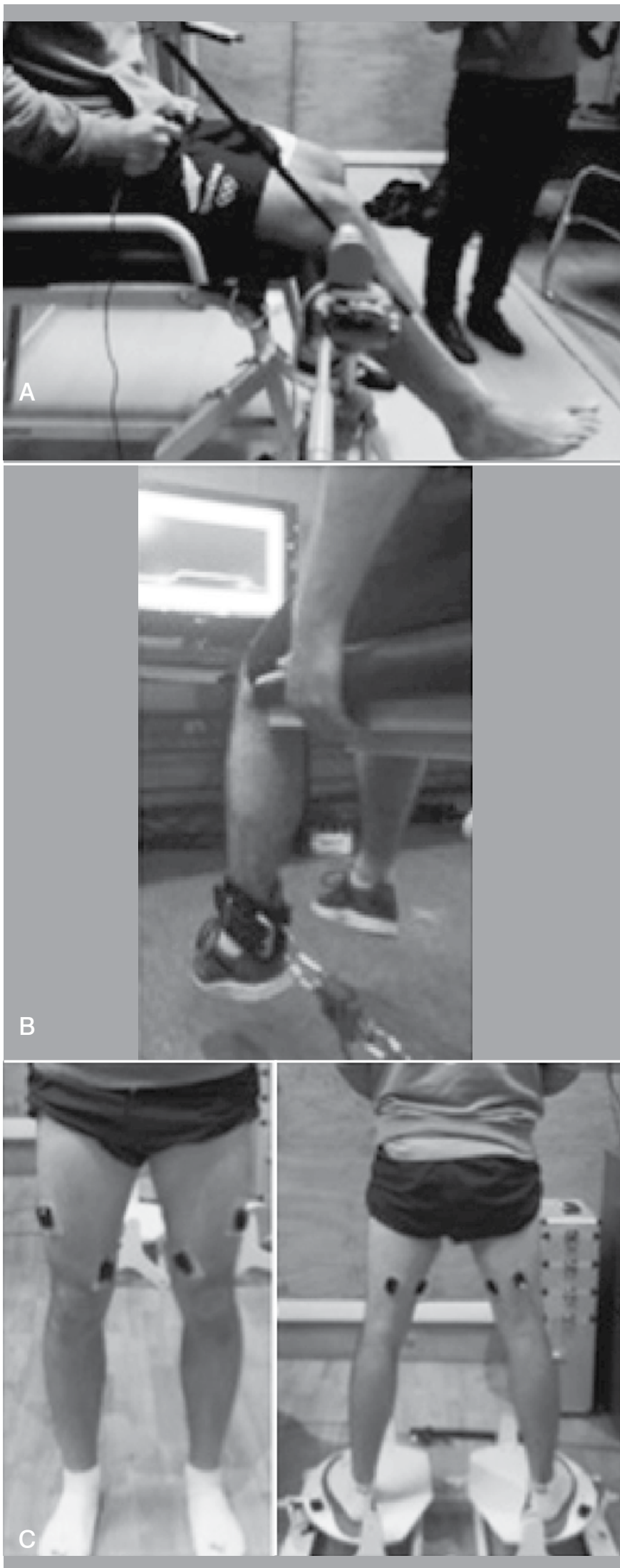

Figure 1. (A) Shows the joint position sense test with the uniaxial electrogoniometer. (B) Shows the steadiness test with the load cell and the paradigm to $15 \%$ of the MVIC. (C) Shows the knee muscle onset test with the position of the sEMG sensors and the platform. 
Each one of the assessments was performed on both extremities in all subjects.

In order to make comparisons, subjects were divided into different groups depending on their individual characteristics (Table 1). In all assessments, each of the data obtained between the different groups was compared.

\section{Statistical analysis}

To evaluate the normal distribution of the data the Shapiro-Wilk test was used. The difference mean test was used in the case of data with normal distribution and the signed rank Wilcoxon test otherwise. A statistically significant result was considered when the $p$ value was less than or equal to 0.05 . STATA 9.1 software was used for the statistical analysis. For the different measured tests (JPS, Steadiness and onset of muscle activation) gender differences, differences between groups with different levels of physical activity, differences between the dominant and non-dominant limb, and differences between right versus left limb of the same subject were compared.

\section{RESULTS}

\section{JPS Test}

A significant difference was found between men and women in the knee JPS test at $90^{\circ}-60^{\circ}(p=0,0127)$ and at $30^{\circ}-0^{\circ}(p=0,0034)$ when comparing the right extremities of both genders (Figure $2 \mathrm{~A}$ ). When comparing left extremities a significant difference was found in the range of $60^{\circ}-90^{\circ}(p=0,0034)$ (Figure $\left.2 \mathrm{~B}\right)$. In both comparisons men had better results.

The group with higher level of physical activity had significantly better values in at $90^{\circ}-60^{\circ}(p=0,0328)$ in the right limb and $30^{\circ}-0^{\circ}$ $(p=0,0173)$ in the left limb compared with the group that performed a lower level of physical activity (Figure $2 \mathrm{C}$ and $2 \mathrm{D}$ ). No significant differences were found when comparing the dominant limb with the non dominant limb, however the results showed that the left limb showed better results in JPS at $60^{\circ}-30^{\circ}(p=0.0048)$ (Figure $2 \mathrm{E}$ ). (Table $2 \mathrm{~A}, \mathrm{~B}$ )

\section{Steadiness}

Women had significant better values compared to men in the right $(p=0,0002)$ and left limb $(p=0,0009)$, (Figure $3 A)$. The group with higher level of physical activity had significant better values in right steadiness $(p=0,0065)$ and left $(p=0,0173)$ compared to the group that performed a lower level of physical activity (Figure $3 \mathrm{~B}$ ). (Table $3 \mathrm{~A}, \mathrm{~B}$ )

\section{Onset of Muscle Activation}

The left limb showed better results in the timing of muscle onset for vastus medialis ( $p=0.0466$ ) when compared with the right leg. (Figure 4 E). (Table 4 A, B)

Table 1. Mean +/- (standard deviation) of demographic data for subjects who complete the 3 evaluations.

\begin{tabular}{c|c|c}
\hline Variable & \multicolumn{2}{|c}{ Groups } \\
\hline Gender & Men $(\mathrm{n}=27)$ & Women $(\mathrm{n}=24)$ \\
\hline $\begin{array}{c}\text { Level of physical activity } \\
\text { Tegner's scale }\end{array}$ & More than $5(\mathrm{n}=28)$ & Less or equal to $5(\mathrm{n}=23)$ \\
\hline Age & Older than 25 years $(\mathrm{n}=18)$ & $\begin{array}{c}\text { Younger or equal to } \\
25 \text { years }(\mathrm{n}=33)\end{array}$ \\
\hline Dominance & $\begin{array}{c}\text { Dominant limb } \\
(\mathrm{n}=51)\end{array}$ & Non dominant limb $(\mathrm{n}=51)$ \\
\hline Extremity & Right $(\mathrm{n}=51)$ & Left $(\mathrm{n}=51)$ \\
\hline
\end{tabular}

Information of each group in which subjects were divided to make comparisons of each evaluation. $\mathrm{n}=$ number of subjects per category.

\section{DISCUSSION}

\section{JPS Test}

Previous studies have demonstrated significant differences between men and women when comparing knee proprioception. ${ }^{3,9}$ In these studies women present reduce proprioception ability, which is consistent with the data obtained in our study where worse values in joint repositioning are shown in the female population in the most extreme measurement ranges $\left(90^{\circ}-60^{\circ}\right.$ y $30^{\circ}-0^{\circ}$ ). A possible explanation for this is that women have greater articular laxity, so capsuloligamentous receptors would need a greater stimulus to trigger a response equal to that of men. ${ }^{1}$ Men also have a higher proportion of muscle mass, which could provide them with more quantity of musculotendinous proprioceptive receptors.

Subjects with a lower level of physical activity also presented worse values in knee JPS. Some studies in professional footballers ${ }^{4}$ and in elite tennis players ${ }^{10}$ agree with our data and confirm that physical activity level is also a factor that can influence the proprioceptive assessment performance. Moreover, higher proprioception ability have been found in competitive athletes .${ }^{11}$ Therefore, it is possible to hypothesized that training enhance the proprioception ability.

In this study no significant differences were found between the dominant and non-dominant limb. However, when comparing the left and right limb (i.e.: without considering dominance) we found better values in the joint repositioning test in the left side. This is consistent with the results published by Daniel J. Goble ${ }^{12}$ , which indicates a close relationship between the left side of the body and the right hemisphere of the brain. Moreover, Natio et al. used a regional map with neuroimaging of the brain's response while applying vibrations to tendons and found that the proprioceptive signals from the proprioceptive receptors generated more information to the right hemisphere of the brain, so the left side of the body should have better proprioceptive values. ${ }^{13,14}$ Therefore, it seems that the left lower limb have better proprioceptive performance.

\section{Steadiness}

The results of the present study also show better steadiness values in the group of women as compared to men, as the study of Brown et al. ${ }^{15}$ According to this study, the main difference in steadiness is attributable to the absolute muscle strength, which is higher in men compare to women. Regarding to the physical activity level, results show that subjects with a higher level of physical activity present better isometric steadiness than sedentary subjects. Different studies have shown that strength training improves isometric steadiness due to sensorimotor control improvements, which would explain the better result in trained subjects. ${ }^{16,17}$ Moreover, this assessment has be related to a greater risk of injury, as seen in various publications that patients with anterior cruciate ligament reconstruction. ${ }^{18}$ Therefore, this assessment provides an insight in muscle function and may be use in other clinical settings.

\section{Onset of Muscle Activation}

No significant differences were found in most of the onset of muscle activation. Nevertheless, other studies have found that healthy people that have greater anterior knee laxity present an increase in timing of muscle onset of biceps femoris. ${ }^{19}$ If there is an increased time of muscle onset, it can compromise joint stability, being similar to what happens when there is a ligament injury and damage to receptors that send the afferent signal, and the signal initiating this reflex may be compromised. 


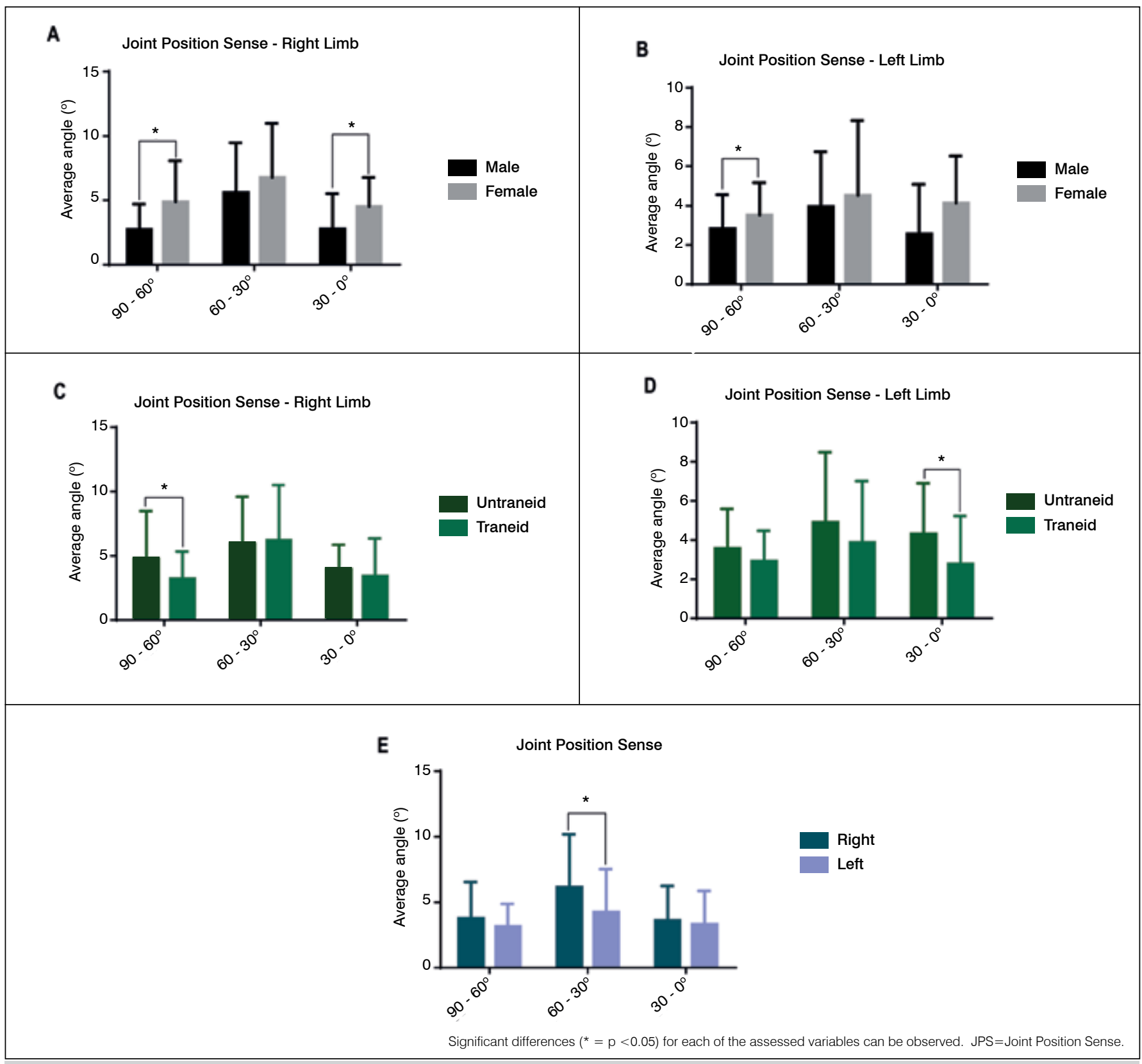

Figure 2. Results for joint position senses (JPS) for the comparisons between male - female, trained - untrained and right limb -left limb. All data shown as median and standard deviation. (A) It shows JPS in degrees for the right limb for males and females. (B) It shows JPS in degrees for the left limb for males and females. (C) It shows JPS in degrees for the right limb for trained and untrained. (D) It shows JPS in degrees for the left limb for trained and untrained. (E) It shows JPS in degrees for the left and right limb.

Table 2 A. Means Angles Values for Joint Position Sense by gender, physical activity or both limbs.

\begin{tabular}{|c|c|c|c|c|c|c|c|c|}
\hline Variable & Indicator & Limb & $\begin{array}{c}\text { Mean } \\
90^{\circ}-60^{\circ}\end{array}$ & SD & $\begin{array}{c}\text { Mean } \\
60^{\circ}-30^{\circ}\end{array}$ & SD & $\begin{array}{c}\text { Mean } \\
30^{\circ}=0^{\circ}\end{array}$ & SD \\
\hline \multirow{4}{*}{ Gender } & \multirow{2}{*}{ Male } & Right & 2,75 & 1,95 & 5,59 & 3,87 & 2,79 & 2,71 \\
\hline & & Left & 2,82 & 1,73 & 3,96 & 2,79 & 2,56 & 2,53 \\
\hline & \multirow{2}{*}{ Female } & Right & 4,88 & 3,18 & 6,78 & 4,20 & 4,52 & 2,25 \\
\hline & & Left & 3,51 & 1,65 & 4,52 & 3,80 & 4,13 & 2,40 \\
\hline \multirow{4}{*}{$\begin{array}{c}\text { Level of } \\
\text { physical activity }\end{array}$} & \multirow{2}{*}{$\begin{array}{c}\text { Tegner } \\
>5\end{array}$} & Right & 3,24 & 2,07 & 6,24 & 4,27 & 3,42 & 2,94 \\
\hline & & Left & 2,93 & 1,53 & 3,88 & 3,13 & 4,92 & 3,55 \\
\hline & \multirow{2}{*}{$\begin{array}{c}\text { Tegner } \\
\leq 5\end{array}$} & Right & 4,77 & 3,71 & 5,97 & 3,62 & 3,97 & 1,89 \\
\hline & & Left & 3,57 & 2,01 & 4,92 & 3,55 & 4,31 & 2,59 \\
\hline \multirow{2}{*}{ Limb } & \multicolumn{2}{|c|}{ Right } & 3,75 & 2,79 & 6,15 & 4,03 & 3,60 & 2,63 \\
\hline & \multicolumn{2}{|c|}{ Left } & 3,14 & 1,71 & 4,22 & 3,28 & 3,30 & 2,57 \\
\hline
\end{tabular}


Table 2 B. Comparison of Means Angles Values for Joint Position Sense between gender, physical activity or both limbs.

\begin{tabular}{|c|c|c|c|c|c|}
\hline Evaluation & Limb & Range & MD & ES & P. Value \\
\hline \multirow{6}{*}{$\begin{array}{l}\text { Differences between gender } \\
\quad(\text { Female - Male) }\end{array}$} & \multirow{3}{*}{ Right } & $90^{\circ}-60^{\circ}$ & 2,12 & 1,95 & $0,0127^{*}$ \\
\hline & & $60^{\circ}-30^{\circ}$ & 1,18 & 1,13 & 0,3358 \\
\hline & & $30^{\circ}-0^{\circ}$ & 1,73 & 0,70 & $0,0017^{*}$ \\
\hline & \multirow{3}{*}{ Left } & $90^{\circ}-60^{\circ}$ & 0,68 & 0,47 & 0,1311 \\
\hline & & $60^{\circ}-30^{\circ}$ & 0,56 & 0,92 & 0,8949 \\
\hline & & $30^{\circ}-0^{\circ}$ & 1,57 & 0,69 & $0,0034^{*}$ \\
\hline \multirow{6}{*}{$\begin{array}{l}\text { Differences between Level of physical activity } \\
\text { (Lower- Higher) }\end{array}$} & \multirow{3}{*}{ Right } & $90^{\circ}-60^{\circ}$ & 1,52 & 0,80 & 0,0328 * \\
\hline & & $60^{\circ}-30^{\circ}$ & -0.27 & 1,20 & 0,4109 \\
\hline & & $30^{\circ}-0^{0}$ & 0,54 & 0,78 & 0,2450 \\
\hline & \multirow{3}{*}{ Left } & $90^{\circ}-60^{\circ}$ & 0,64 & 0,50 & 0,1062 \\
\hline & & $60^{\circ}-30^{\circ}$ & 1,03 & 0,97 & 1,0374 \\
\hline & & $30^{\circ}-0^{\circ}$ & 1,51 & 0,74 & 0,0229 * \\
\hline \multirow{3}{*}{$\begin{array}{l}\text { Differences between Both Limbs } \\
\text { (right - left) }\end{array}$} & & $90^{\circ}-60^{\circ}$ & 0,60 & 0,45 & 0,0941 \\
\hline & & $60^{\circ}-30^{\circ}$ & 1,92 & 0,72 & 0,0048 * \\
\hline & & $30^{\circ}-0^{\circ}$ & 0,30 & 0,51 & 0,2531 \\
\hline
\end{tabular}

${ }^{*} \mathrm{P}<0,05$. Abbreviations: $\mathrm{MD}=$ Mean Difference. $\mathrm{ES}=$ Error Standard

A

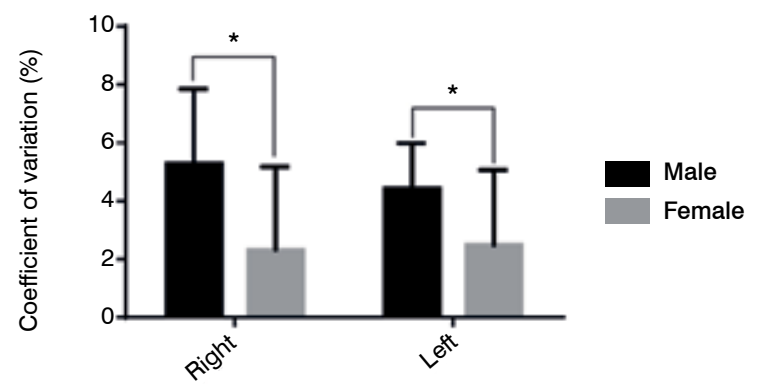

B

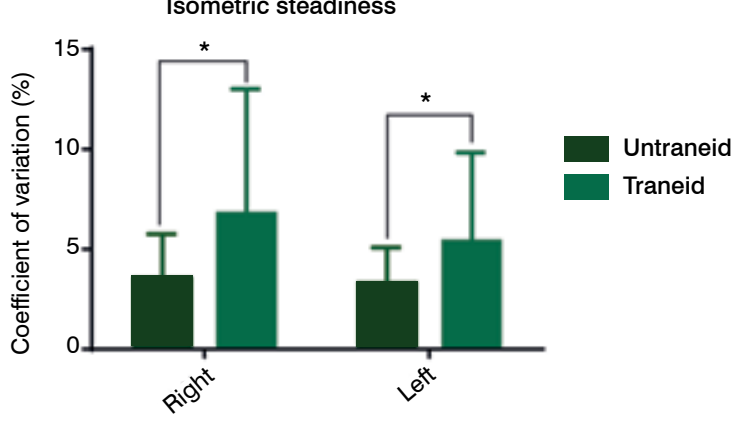

C Isometric steadiness

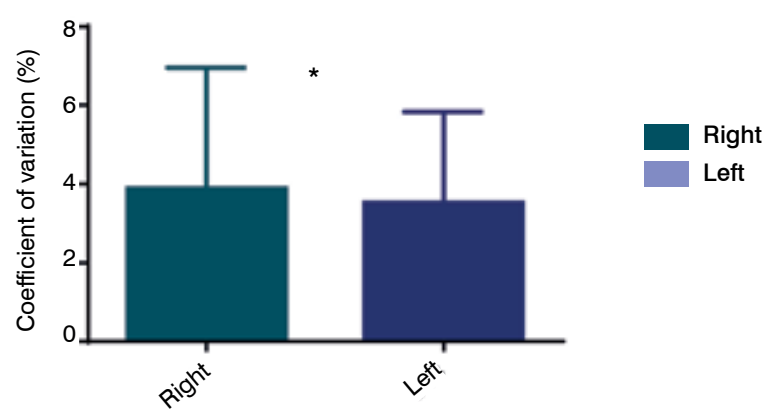

Significant differences $\left({ }^{*}=p<0.05\right)$ for each of the assessed variables can be observed

Figure 3. Results for isometric steadiness for the comparisons between male - female, trained - untrained and right limb -left limb. All data shown as median and standard deviation. (A) It shows the coefficient of variation for the isometric steadiness for males and females. (B) It shows the coefficient of variation for the isometric steadiness for trained and untrained. (C) It shows the coefficient of variation for the isometric steadiness for right limb and left limb.

Table 3 A. Mean Percentages for Values Steadiness by gender, physical activity or limb evaluated

\begin{tabular}{c|c|c|c|c|c}
\hline \multirow{2}{*}{ Variable } & Indicator & $\begin{array}{c}\text { Right Limb } \\
\text { Mean }\end{array}$ & SD & $\begin{array}{c}\text { Left Limb } \\
\text { Mean }\end{array}$ & SD \\
\hline \multirow{2}{*}{ Gender } & Male & 5,28 & 2,57 & 4,44 & 1,55 \\
\cline { 2 - 6 } & Female & 2,32 & 2,86 & 2,49 & 2,58 \\
\hline \multirow{2}{*}{$\begin{array}{c}\text { Level of physical } \\
\text { activity }\end{array}$} & Tegner $>5$ & 3,50 & 2,24 & 3,28 & 1,79 \\
\cline { 2 - 6 } & Tegner $\leq 5$ & 6,71 & 6,23 & 5,38 & 4,45 \\
\hline \multicolumn{2}{c}{ Limb } & 3,88 & 3,07 & 3,52 & 2,30 \\
\hline
\end{tabular}

Values expressed in percentage. Abbreviations: SD: Standard Deviation.
Table 3 B. Comparison of Mean Percentage for Values Steadiness by differences between gender, physical activity or both limbs.

\begin{tabular}{c|c|c|c|c}
\hline Evaluation & Limb & MD & ES & P. Value \\
\hline Gender & Right & $-2,90$ & 0,70 & $0,0002^{*}$ \\
\cline { 2 - 5 } $\begin{array}{c}\text { (Female - Male) } \\
\text { Left }\end{array}$ & $-1,90$ & 0,50 & $0,0009^{*}$ \\
\hline $\begin{array}{c}\text { Level of physical activity } \\
\text { (Lower - Higher) }\end{array}$ & Right & 3,20 & 1,20 & $0,0065^{*}$ \\
\cline { 2 - 5 } & Left & 2,00 & 0,90 & $0,0173^{*}$ \\
\hline $\begin{array}{c}\text { Limb } \\
\text { (right - left) }\end{array}$ & & 0,30 & 0,50 & 0,2531 \\
\hline
\end{tabular}

${ }^{*} \mathrm{P}<0,05$. Abbreviations: $M D=$ Mean Difference. $E S=$ Error Standard 


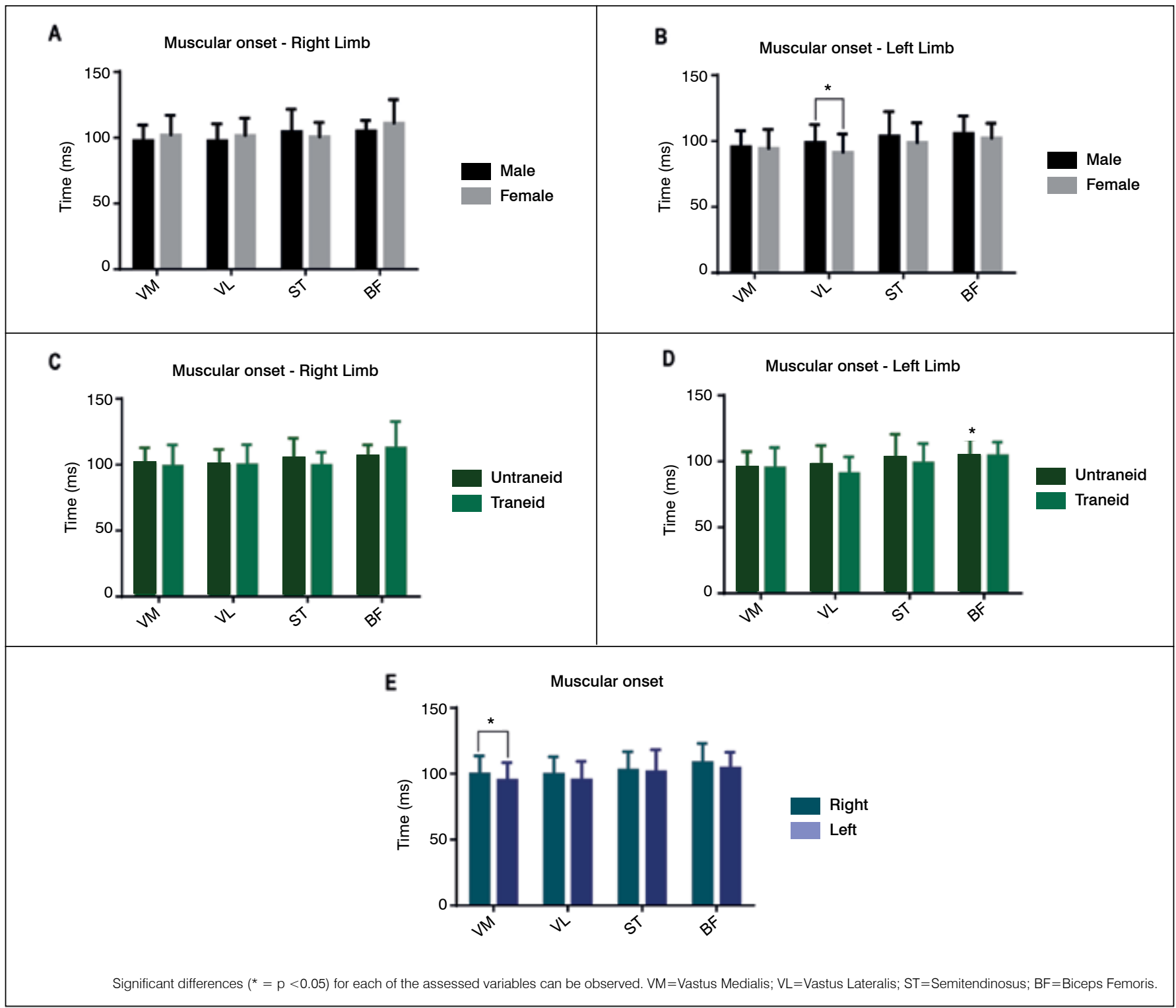

Figure 4. Results for muscular onset for the comparisons between male - female, trained - untrained and right limb -left limb. All data shown as median and standard deviation. (A) It shows time of muscular onset for the right limb, for males and female. (B) It shows time of muscular onset for the left limb, for males and females. (C) It shows time of muscular onset for the right limb, for trained and untrained. (D) It shows time of muscular onset for the left limb, for trained and untrained. (E) It shows time of muscular onset for the right limb and left limb.

Table 4 A. Mean Values for time of Muscle Onset by gender, physical activity and both limbs.

\begin{tabular}{|c|c|c|c|c|c|c|c|c|c|c|}
\hline Variable & Indicator & Limb & MV Mean & SD & LV Mean & SD & ST Mean & SD & FB Mean & SD \\
\hline \multirow{4}{*}{ Sex } & \multirow{2}{*}{ Male } & Right & 97,57 & 12,01 & 97,42 & 13,19 & 104,74 & 16,83 & 105,07 & 8,12 \\
\hline & & Left & 95,61 & 12,31 & 98,94 & 13,57 & 103,87 & 18,49 & 105,85 & 13,25 \\
\hline & \multirow{2}{*}{ Female } & Right & 102,0 & 15,07 & 101,72 & 13,12 & 100,64 & 10,89 & 111,12 & 17,81 \\
\hline & & Left & 94,38 & 14,61 & 91,42 & 14,00 & 98,98 & 14,95 & 102,25 & 11,31 \\
\hline \multirow{4}{*}{$\begin{array}{l}\text { Level of physical } \\
\text { activity }\end{array}$} & \multirow{2}{*}{ Tegner $>5$} & Right & 100,45 & 12,32 & 99,43 & 12,20 & 104,32 & 15,85 & 105,83 & 9,29 \\
\hline & & Left & 94,91 & 12,51 & 97,45 & 14,64 & 102,87 & 17,78 & 103,87 & 13,44 \\
\hline & \multirow{2}{*}{ Tegner $\leq 5$} & Right & 98,76 & 16,26 & 99,95 & 15,23 & 99,53 & 9,87 & 112,73 & 20,07 \\
\hline & & Left & 95,06 & 15,32 & 90,83 & 12,54 & 98,63 & 14,90 & 104,23 & 10,46 \\
\hline \multirow{2}{*}{\multicolumn{2}{|c|}{$\begin{array}{l}\text { Limb } \\
\text { Left }\end{array}$}} & Right & 99,85 & 13,69 & 99,62 & 13,18 & 102,69 & 14,16 & 108,48 & 14,57 \\
\hline & & 94,97 & 13,42 & 95,09 & 14,15 & 101,42 & 16,80 & 104,00 & 12,28 & \\
\hline
\end{tabular}

Values expressed in milliseconds. Abbreviations: SD: Standard Deviation. MV= Medial Vastus. LV= Lateral Vastus. ST= Semitendinosus. FB= Femoral Biceps. 
Table 4 B. Comparison between Mean for time of Muscle Onset by differences between gender, physical activity and both limbs.

\begin{tabular}{|c|c|c|c|c|c|}
\hline Evaluation & Limb & Muscle & MD & ES & P. Value \\
\hline \multirow{8}{*}{ Gender (Female - Male) } & \multirow{4}{*}{ Right } & MV & 4,46 & 4,07 & 0,2858 \\
\hline & & LV & 4,29 & 3,92 & 0,2287 \\
\hline & & ST & $-4,10$ & 4,27 & 0,6555 \\
\hline & & $\mathrm{BF}$ & 6,04 & 4,66 & 0,3012 \\
\hline & \multirow{4}{*}{ Left } & MV & $-1,23$ & 4,09 & 0,7421 \\
\hline & & LV & $-7,51$ & 4,11 & $0,0357^{*}$ \\
\hline & & ST & $-4,89$ & 5,07 & 0,4595 \\
\hline & & $\mathrm{BF}$ & $-3,60$ & 3,75 & 0,6269 \\
\hline \multirow{8}{*}{ Level of physical activity (Lower - higher) } & \multirow{4}{*}{ Right } & MV & $-1,68$ & 4,30 & 0,3487 \\
\hline & & LV & 0,52 & 4,15 & 0,4504 \\
\hline & & ST & $-4,79$ & 4,49 & 0,1464 \\
\hline & & $\mathrm{BF}$ & 6,90 & 4,72 & 0,0763 \\
\hline & \multirow{4}{*}{ Left } & MV & 0,15 & 4,25 & 0,4860 \\
\hline & & LV & $-6,62$ & 4,34 & 0,0675 \\
\hline & & ST & $-4,23$ & 5,36 & 0,2175 \\
\hline & & $\mathrm{BF}$ & 0,36 & 3,92 & 0,4631 \\
\hline \multirow{4}{*}{ Limb (right - left) } & & MV & 4,88 & 2,87 & $0,0466^{*}$ \\
\hline & & LV & 4,52 & 2,88 & 0,0602 \\
\hline & & ST & 1,26 & 3,31 & 0,3516 \\
\hline & & $\mathrm{BF}$ & 4,47 & 2,96 & 0,0677 \\
\hline
\end{tabular}

${ }^{\star} \mathrm{P}<0,05$. Abbreviations: $\mathrm{MD}=$ Mean Difference. $\mathrm{ES}=$ Error Standard. $\mathrm{MV}=$ Medial Vastus. $\mathrm{LV}=$ Lateral Vastus. ST= Semitendinosus. FB= Femoral Biceps.

\section{CONCLUSION}

Men presented better JPS and steadiness that women, which may be attributable to a higher laxity of women and higher muscle strength of men, respectively. Subjects with higher training showed better JPS and steadiness values. This is consistent with the literature, where training results in sensorimotor adaptation.

AUTHORS' CONTRIBUTIONS: All authors contributed individually and significantly to the development of this article. CSM (0000-0001-9913-3310)*: wrote and reviewed the manuscript, contributed to the intellectual conceptualization of the study and the entire research project. AV: wrote and reviewed the manuscript. IC (0000-0003-3831-6513)*: performed measurements for the assessments and outcome assessment analysis. FJB (0000-0003-3552-8262)*: contributed to the intellectual conceptualization of the study and reviewed the manuscript. CO (0000-0001-7240-1928)*: performed the statistical analysis and reviewed the manuscript. FL (0000-0001-9255-2555)*: performed measurements for the assessments and wrote the manuscript. *ORCID (Open Researcher and Contributor ID).

\section{REFERENCES}

1. Riemann BL, Lephart SM. The sensorimotor system, part I: the physiologic basis of functional joint stability. J Athl Train. 2002;37(1):71.

2. Myers JB, Wassinger CA, Lephart SM. Sensorimotor contribution to shoulder stability: effect of injury and rehabilitation. Man Ther. 2006;11(3):197-201.

3. Nagai T, Sell TC, Abt JP, Lephart SM. Reliability, precision, and gender differences in knee internal/external rotation proprioception measurements. Phys Ther Sport. 2012;13(4):233-237.

4. Muaidi Q, Nicholson L, Refshauge K. Do elite athletes exhibit enhanced proprioceptive acuity, range and strength of knee rotation compared with non-athletes? Scand J Med Sci Sports. 2009;19(1):103-112

5. Tegner $Y$, Lysholm J. Rating systems in the evaluation of knee ligament injuries. Clin Orthop Relat Res. 1985;198:42-49.

6. Tracy BL, Enoka RM. Older adults are less steady during submaximal isometric contractions with the knee extensor muscles. J. Appl. Physiol. 2002;92(3): 1004-1012.

7. Riemann BL, Myers JB, Lephart SM. Sensorimotor system measurement techniques. J Athl Train. 2002;37(1):85.

8. Hermens HJ, Freriks B, Merletti R, et al. European recommendations for surface electromyography. Roessingh Research and Development. 1999;8(2):13-54.

9. Karkousha RN. Sex differences of knee joint repositioning accuracy in healthy adolescents. Bull Fac Phys Ther. 2016;21(1):56.

10. Lin C-H, Lien Y-H, Wang S-F, Tsauo J-Y. Hip and knee proprioception in elite, amateur, and novice tennis players. Am J Phys Med Rehabil. 2006;85(3):216-221.
11. Han J, Waddington G, Anson J, Adams R. Level of competitive success achieved by elite athletes and multi-joint proprioceptive ability. J Sci Med Sport. 2015;18(1):77-81.

12. Goble DJ, Brown SH. Upper limb asymmetries in the matching of proprioceptive versus visual targets. J Neurophysiol. 2008;99(6):3063-3074.

13. Naito E, Nakashima T, Kito T, Aramaki Y, Okada T, Sadato N. Human limb-specific and non-limb-specific brain representations during kinesthetic illusory movements of the upper and lower extremities. Eur J Neurosci. 2007;25(11):3476-3487.

14. Naito E, Roland PE, Grefkes C, et al. Dominance of the right hemisphere and role of area 2 in human kinesthesia. J Neurophysiol. 2005;93(2):1020-1034.

15. Brown RE, Edwards DL, Jakobi JM. Sex differences in force steadiness in three positions of the forearm. Eur J Appl Physiol. 2010;110(6):1251-1257.

16. Bilodeau M, Keen DA, Sweeney PJ, Shields RW, Enoka RM. Strength training can improve steadiness in persons with essential tremor. Muscle Nerve. 2000;23(5):771-778.

17. Keen DA, Yue GH, Enoka RM. Training-related enhancement in the control of motor output in elderly humans. J Appl Physiol (1985). 1994;77(6):2648-2658.

18. Telianidis S, Perraton L, Clark RA, Pua Y-H, Fortin K, Bryant AL. Diminished sub-maximal quadriceps force control in anterior cruciate ligament reconstructed patients is related to quadriceps and hamstring muscle dyskinesia. $J$ Electromyogr Kinesiol. 2014;24(4):513-519.

19. Shultz SJ, Carcia CR, Perrin DH. Knee joint laxity affects muscle activation patterns in the healthy knee. J Electromyogr Kinesiol. 2004;14(4):475-483. 